\section{ACTUAL PROBLEMS OF EPSTEIN-BARR VIRAL INFECTION DIAGNOSTICS}

N.H. Zavidnyuk

SUMMARY.The article presents brief historical landmarks of Epstein-Barr virus discovery. The features of its structure and life, some viral antigens are characterized. Its effect on the immune system is described. The current views on the pathogenesis and clinical picture of infectious mononucleosis and chronic $E B V$-infection are displaying, approaches to diagnosis using serological methods as well as PCR.

Key words: Epstein-Barr virus infection, infectious mononucleosis, viral antigens, the immune system.

Отримано 23.11.2015 p.

\title{
ГЕРПЕС-АСОЦІЙОВАНА БАГАТОФОРМНА ЕКСУДАТИВНА ЕРИТЕМА
}

Тернопільський державний медичний університет ім. І.Я. Горбачевського

Висвітлено аспекти етіології, патогенезу, діагностики, лікування і профрілактики герпес-асоційованої багатоформної еритеми. Наведено основні аспекти проведення дифреренційної діагностики між великою, малою фрормами цієї еритеми і синдромом СтівенсаДжонсона.

Ключові слова: багатоформна еритема, вірус простого герпесу, ураження шкіри.

Незабаром після перших повідомлень про зв'язок багатофрормної еритеми (БЕ) і «бульбашкового лишаю», опублікованих у 1933 p. Urbach, Anderson вже назвав вірус простого герпесу (ПГ) «міною уповільненої дії» щодо даного дерматозу. 80 років, які минули з того часу, не тільки не змінили ситуацію, а й надали їй особливої актуальності. Якщо на початкових етапах вивчення цього процесу основним був пошук причинних фракторів, то сьогодні стоять інші завдання, пов'язані з дослідженням патогенезу і підбором терапії [1-5].

Виявлено чимало збудників, які можуть бути поштовхом до розвитку частого різновиду еритеми - їі інфекційно-алергічної фрорми. У багатьох дослідженнях, проведених з використанням сучасних діагностичних технологій, доведена етіологічна роль вірусу Пг, його безпосередній зв'язок як із дебютом захворювання, так і з подальшими рецидивами. Згідно зі статистичними даними про звертання у спеціалізовані клініки, питома частка БЕ, викликаної вірусом ПГ, серед усіх її фрорм досягає 80 \%, що становить близько 1 \% усіх пацієнтів, які звертаються до дерматовенеролога [6-8].

За даними ВОО3, актуальності проблемі додає зростання захворюваності на ПГ, показники якої вийшли на одне з перших місць, укупі з такими інфекціями, як вірус імунодефіциту людини і грипу.

У сучасній науковій літературі особливостям вірусу ПГ, як клінічним, так і імунологічним, присвячена велика кількість досліджень і, відповідно, публікацій [9-12]. Однак досі немає повідомлень про клінічні риси й особливості імунологічного статусу пацієнтів з ПГ, у яких розвивається герпес-асоційована багатоформна еритема (ГАБЕ). Втім, при отриманні подібних даних виникає можливість прогнозувати ступінь ймовірності розвитку ГАБЕ. Це своєю чергою, забезпечує можливість профрілактики цього дерматозу шляхом активної терапії пацієнтів, які входять до групи ризику.

На сьогодні існує багато препаратів для лікування Пг. їх можна поділити на дві основні групи - етіологічної дії (це синтетичні нуклеозиди) і засоби, спрямовані на імуностимуляцію, які представляють собою більш численну групу. Однак, незважаючи на широкий вибір препаратів для лікування ПГ, у разі розвитку на його фоні еритеми рекомендації в основному зводяться до 
призначення синтетичних нуклеозидів. Їх застосовують зазвичай для купірування поточного рецидиву. Як профрілактичний метод, у більшості сучасних посібників рекомендують постійний прийом ацикловіру. На жаль, на сьогодні в усьому світі відзначено розвиток резистентних до ацикловіру штамів вірусу. Тому є актуальним пошук альтернативних методів профрілактики рецидивів ПГ, що призводять до розвитку ГАБЕ $[13,14]$.

Серед останніх можна виділити герпетичну вакцину, яка є препаратом специфрічного імунного впливу і широко застосовується 31933 р. За даними щодо результатів лікування пацієнтів з ПГ у різних країнах, її ефрективність складає від 30 до 80 \%, тобто терапія з використанням герпетичної вакцини посідає міцні позиції в ряду препаратів імунної спрямованості. Вибір неспецисічних імуномодуляторів внаслідок відсутності чітких показань найчастіше має емпіричний характер. У такій ситуації актуальним $€$ використання герпетичної полівакцини, як специфрічного і економічно доступного засобу профрілактики рецидивів ПГ, що призводить до розвитку БЕ.

БЕ - це гостре захворювання шкіри, що характеризується раптовою появою симетричних фріксованих червоних вузликів, частина яких перетворюється в типові та/ або зрідка «атипові» вузлові мішенеподібні елементи. Цей висип часто викликає інфекція, особливо вірус Пг. Розрізняють дві фрорми БЕ - велика і мала багатоформна еритема. Для обох характерний однаковий тип первинних уражень (мішені), але відрізняються вони наявністю чи відсутністю ураження слизової оболонки і загальними симптомами. У переважної більшості хворих клінічно БЕ можна відрізнити від синдромів Стівенса-Джонсона і Лайєла, ґрунтуючись на визначенні типу первинних уражень шкіри і їх розподілі [4, 14-16.

БЕ вперше описав австрійський дерматолог Фердинанд фон Гебра в 1860 р. Захворювання, яке він описав, було легким, з раптовим виникненням сотень червоних вузликів. Шляхом щоденного спостереження фон Гебра зареєстрував ті самі початкові вузлики, що перетворюються в ураження 3 концентричними зонами зміни кольору, яким він дав ім'я «мішенеподібні елементи». Однак фон Гебра не описав ні продромального періоду, ні уражень слизових оболонок. Він встановив, що цей стан був рецидивним, і згадав «щорічний тип», який рецидивував щоосені.

Пізніше, в 1950 р., Бернард Томас поділив БЕ на велику і малу форми. Він вважав, що хвороба фон Гебра $€$ малою фрормою БЕ, а тяжкий некроз слизових оболонок 3 шкірними висипаннями, подібними БЕ, - великою формою захворювання. 31950 р. визначення БЕ було неоднозначним, частково тому, що деякі автори, особливо в США, констатували, що велика фрорма БЕ включає синдром Стівенса-Джонсона. Однак сучасні науковці переконливо стверджують, що термін «мала фрорма БЕ» слід зберегти за хворобою фон Гебрі, а термін «велика форма БЕ» слід використовувати для БЕ, пов'язаної 3 ураженнями слизових оболонок і загальними симптомами, але не для опису синдрому Стівенса-Джонсона, тому останній і велика форма БЕ є окремими клінічними захворюваннями.

Епідеміологія. БЕ переважно спостерігають у молодих людей і дуже рідко - в дитячому віці. Приблизно 20 \% всіх випадків БЕ зустрічається в дитинстві. $€$ невелике переважання кількості випадків захворювання на БЕ в осіб чоловічої статі, але без расових відмінностей. Точний рівень захворюваності на цю патологію невідомий.

Патогенез. Вважають, що БЕ у більшості хворих найімовірніше $€$ шкірно-слизовим проявом особливої, спрямованої на шкіру імунної реакції, яка спостерігається в умовах інфекції у схильних осіб. Вірус простого герпесу $є$ найчастішим інфекційним фактором, a Mycoplasma pneumoniae, Histoplasma capsulatum i Parapoxvirus спостерігають рідше. Повідомлялося, що БЕ, пов'язана з гістоплазмозом, зустрічається частіше у хворих із супутньою вузлуватою еритемою, дані про вірус Епштейна-Барр як пусковий фрактор неповні. Рідше БЕ пов'язана з ліками або системними захворюваннями. Однак необхідно враховувати можливість синдрому Стівенса-Джонсона, генералізованої фріксованої еритеми, висипання при поліморфній лікарській екзантемі або кропив'янці, якщо можливим діагнозом є медикаментозно індукована БЕ. Варто зазначити, що кілька фрізичних фракторів, наприклад травма, холод, ультрасріолетове й електронне випромінювання високої напруги, описані як пускові чинники БЕ, пов'язаної з інфекціями, ліками або системними захворюваннями.

На сьогодні не існує чітко визначеної генетичної схильності до розвитку БЕ. Кілька невеликих досліджень зв'язку антигенів HLA виявили різні асоціації: HLA-DQw3, DRw53 і Aw33. Ці HLA-асоціації відрізняються від аcoціацій, описуваних для синдрому Стівенса-Джонсона і TEH [17].

Цілий ряд місцевих препаратів, за повідомленнями, пов'язаний з БЕ. Цей перелік включає протиінфекційні засоби (хлораморенікол, еконазол, лінкоміцин, неоміцин, сульсраніламіди), консерванти (формальдегід, етилендіамін), сенсибілізатори (динітрохлорбензол, дифенілциклопропанон), аромати (перуанський бальзам), кетопрофрен і місцеві кортикостероїди (будесонід, тріамцинолон) [1].

Вірус простого герпесу (ВПГ). У більшості дітей і дорослих з БЕ це захворювання викликає ВПГ 1-го і 2-го типів. Попередній ПГ губ відзначається приблизно у 50 \% осіб з БЕ. ПГ губ може передувати початку уражень шкіри, спостерігатися одночасно або проявлятися після 
того, як мішенеподібні елементи БЕ вже з'явилися. Найчастіше герпес губ передує виникненню мішенеподібних уражень БЕ за 3-14 днів. Припускають, що більшість випадків у дітей і молодих людей обумовлено ВПГ 1-го типу, але повідомлялося про підтверджені випадки ВПг 2-го типу у цієї категорії хворих.

Більша частина сучасних знань щодо БЕ пов'язана з дослідженням герпес-асоційованої (ГА) БЕ $[11,14,18]$. В межах ураженого епідермісу наявні не тільки кодовані ВПГ білки, але і ДНК ВПГ, які можна виявити в початкових червоних вузликах або зовнішній зоні мішенеподібних елементів у 80 \% осіб з БЕ. Присутність фррагментів ДНК ВПГ (найчастіше складених з послідовностей, які кодують його ДНК-полімеразу) в межах шкірних уражень, а також експресію кодованих вірусом антигенів на кератиноцитах можна тлумачити як доказ на користь реплікації ВПГ у межах ділянок ураженої шкіри. Однак реплікація повинна бути на низькому рівні, тому зазвичай ВПГ неможливо культивувати з уражень БЕ.

Вважають, що запалення в уражених ділянках шкіри $€$ частиною ВПГ-специфрічної відповіді господаря. Особи з ГАБЕ мають нормальний імунітет до ВПГ, але, можливо, у них $є$ перешкода для видалення цього вірусу 3 інорікованих клітин; в ділянках ураженої шкіри ДНК ВПГ може зберігатися впродовж 3 місяців, навіть після того, як ураження вже зажило. Розвиток шкірних уражень запускається послідовностями ДНК ВПГ у шкірі і рекрутуванням вірус-специфрічних клітин Т-хелперів 1-го типу, які виробляють $\gamma$-інтерферон у відповідь на вірусні антигени у шкірі. Вважають, що за цим слідує «автоімунна» відповідь, що виникає у результаті рекрутування Т-клітин, які відповідають на автоантигени, котрі вивільняються лізованими / апоптозними клітинами, що містять вірусний антиген. Зовсім недавно було продемонстровано, що описані вище фррагменти ДНК ВПГ транспортуються попередниками клітин Лангерганса CD-34 периферійної крові в місця, в яких розвиватимуться ураження шкіри БЕ.

Клінічна картина. Через певну клінічну подібність майже до останнього часу вважали, що велика і мала форми БЕ, синдроми Стівенса-Джонсона і Лайєла є частиною спектра одного захворювання. Однак в даний час $€$ вагомий доказ на користь того, що БЕ $є$ захворюванням, відмінним від синдромів Стівенса-Джонсона і Лайєла на декількох рівнях - клінічному, прогностичному та етіологічному. Клінічні критерії дозволяють відрізняти обидві фрорми БЕ від синдромів Стівенса-Джонсона і Лайєла у переважної більшості хворих. Цими клінічними критеріями $€$ такі.

1. Тип первинного ураження шкіри;

2. Розподіл уражень шкіри (топографрія);

3. Наявність або відсутність явних уражень слизових оболонок;
4. Наявність або відсутність загальних симптомів.

Первинні шкірні ураження. Характерним первинним шкірним ураженням БЕ $є$ типовий мішенеподібний елемент. Останній має розмір менше 3 см в діаметрі, правильні округлі обриси і добре окреслений край та складається принаймні з трьох виразних зон, наприклад із двох концентричних кілець зі зміненим кольором, які оточують центральну кругову зону, що має ознаки пошкодження епідермісу у фрормі міхура або кірки. Такий типовий мішенеподібний елемент іноді називають «ураженням-райдужкою» через його веселкоподібний зовнішній вигляд.

Початкові мішенеподібні елементи часто мають центральну темну і червону зовнішню зони, але можуть розвиватися в три зони зміни кольору. Кожне концентричне кільце в межах мішенеподібного елемента, найімовірніше, являє собою результат того ж самого тривалого патологічного процесу. Це може пояснити, чому деякі пацієнти мають тільки обмежену кількість повністю розвинених типових мішеней серед цілого ряду мішенеподібних елементів, які ще не типові або не повністю розвинені, тоді як в інших всі ці ураження знаходяться на тій же самій стадії розвитку, створюючи, таким чином, мономорфний клінічний прояв. 3 урахуванням можливості того, що може бути присутня тільки незначна кількість типових мішенеподібних елементів, дуже важливий повний огляд шкіри [1, 2, 6, 7, 9, 13, 18].

При БЕ атипові вузлові мішенеподібні елементи можуть або супроводжувати типові елементи, або складати первинне шкірне ураження. Ці особливі ураження визначаються як округлі, набряклі, нагадують БЕ, але тільки з двома зонами та/або погано обмеженим краєм. їх необхідно відрізняти від плоских (плямистих) атипових мішеней, які спостерігаються при синдромі СтівенсаДжонсона і ТЕН, але не при БЕ.

Розподіл шкірних уражень. Хоча існують значні коливання у різних індивідуумів, зазвичай при вказаній патології наявні численні ураження. Взагалі ураження БЕ розвиваються переважно на кінцівках і обличчі; мішенеподібні елементи, так само як і всі висипання БЕ, локалізуються на верхніх кінцівках. Тильна поверхня кистей і передпліччя є найчастішою мішенню БА, але долоні, шия, обличчя і тулуб також є поширеними локалізаціями. Ураження гомілок спостерігається рідше. Також елементи БЕ можуть 3'являтися в межах ділянок сонячних опіків. Крім того, висипання мають тенденцію групуватися, особливо на ліктях і колінах. Може спостерігатися френомен Кебнера, причому мішенеподібні елементи з'являються на ділянках пошкодження шкіри, наприклад, при розчухах або як еритема і набряк проксимальних нігтьових валиків у місцях хронічного самотравмування. Це пошкодження зазвичай передує 
початку висипання БЕ, тому феномен Кебнера не виявляється, коли ураження БЕ вже з'явилися [9, 19].

Ураження слизових оболонок. Тяжке ураження слизової оболонки є характерною ознакою великої форми БЕ. При малій формі БЕ ураження слизової зазвичай відсутні, а коли $є$ - то небагато і вони помірносимптоматичні. Первинні ураження слизової везикулобульозні і швидко перетворюються на болючі ерозії, які уражають слизову губ і щік, а також слизові очей і статевих органів. На губах ерозії швидко вкриваються болісними кірками.

Загальні симптоми. Загальні симптоми майже завжди визначаються при великій фрормі БЕ і відсутні або обмежені при малій. При великій фрормі БЕ цими загальними симптомами, які зазвичай передують ураженню шкіри або супроводжують їх, є лихоманка і слабість різного ступеня. Артралгії з набряком суглоба іноді описували так само, як ураження легень, подібні атиповій пневмонії. Ниркові, печінкові або гематологічні порушення в контексті великої фрорми БЕ рідкісні.

Об'єднавши ці чотири клінічних критерії, можна зробити розмежування між великою та малою формами БЕ і синдромом Стівенса-Джонсона.

Природний перебіг. При БЕ хворі вказують в анамнезі на раптову появу шкірних висипань, причому майже всі ці ураження з'являються впродовж 24 год і повного розвитку досягають за 72 год. Окремі елементи залишаються фріксованими на цьому ж самому місці впродовж 7 днів і більше. Хворі відчувають почуття свербіння і печіння в уражених місцях.

У більшості осіб з БЕ епізод триває 2 тижні, загоєння відбувається без ускладнень; можливим рідкісним винятком $є$ очні ускладнення в умовах великої форми БЕ, які можуть спостерігатися, якщо негайно не розпочатий належний догляд за очима. Іноді наявна постзапальна гіпер- або гіпопігментація. У хворих на БЕ клінічний перебіг зазвичай неускладнений, хоча рецидиви у разі ГАБЕ досить поширені. Один рецидив, як описував фон Гебра, може виникати щоосені. Більшість хворих з рецидивуючою ГАБЕ мають один або два епізоди на рік, а винятком є пацієнти, які отримують імуносупресивні препарати. Використання імуносупресивних засобів, таких як кортикостероїди, може бути пов'язане з більш частими і більш тривалими епізодами БЕ. Ці особи можуть мати 5 або 6 епізодів впродовж року або майже безперервне захворювання, при якому один напад ще не повністю виліковується, як спостерігається інший. Також збільшується частота вторинних бактерійних інсекцій з тривалим застосуванням кортикостероїдів.

Гістопатологія. БЕ є клініко-патологічним, а не тільки гістологічним діагнозом. Гістологічні дані характерні, але неспецисрічні, і використовуються при проведенні диференційної діагностики тільки для виключення захворювань, наприклад червоного вовчака і васкуліту. При БЕ кератиноцити $€$ мішенню запального ушкодження, а апоптоз окремих кератиноцитів $€$ найбільш ранньою патологічною знахідкою. У міру того, як розвивається процес, спостерігаються спонгіоз і фрокальна вакуольна дегенерація базальних кератиноцитів. Видно також поверхневий дермальний набряк і навколосудинні інфрільтрати мононуклеарних лейкоцитів і Т-лімфоцитів. Імунофрлуоресцентні дані неспецисрічні.

Компонент дермального запалення при БЕ помітніший, а компонент епідермального некролізу - більш ізольований, порівняно з синдромом Стівенса-Джонсона. При БЕ не спостерігають великих пластів епідермального некрозу.

Диференційний діагноз. Багато фрахівців (недерматологів) гіпердіагностують БЕ, відносячи осіб 3 кропив'янкою до категорії БЕ. Тому необхідно суворо дотримуватися клінічних критеріїв Brice і співавт. для розмежування БЕ та кропив'янки.

Клінічна картина багатьох захворювань може включати утворення мішенеподібних елементів і нагадувати БE, включаючи раніше згадану кропив'янку, фріксовану медикаментозну еритему, підгострий шкірний червоний вовчак, кільцеподібну відцентрову еритему і кілька фрорм васкулітів. Для виключення цих захворювань використовують біопсію шкіри. Допомагає у встановленні діагнозу виявлення загальної кількості уражень (сотні), але важливо також спробувати визначити кількість уражень, які були при першому спалаху захворювання (при фріксованій медикаментозній еритемі висипань менше).

Рецидивна БЕ в дитинстві може мімікрувати у поліморфну світлову реакцію або ювенільне весняне висипання, які можуть бути викликані сонцем і розвиватися 3 першим значним впливом сонця навесні. У хворих на системний червоний вовчак рідкісні окремі ураження можуть імітувати справжні мішенеподібні ураження БЕ, але інші ураження, характерні для червоного вовчака, зазвичай теж наявні. Початкові ураження при васкуліті, особливо уртикарному, можуть імітувати мішенеподібні елементи БЕ. Потрібна біопсія шкіри, щоб виключити як системний червоний вовчак, так і васкуліт; додаткові ознаки - підвищені ШОЕ, автоантитіла і низькі сироваткові рівні комплементу.

Лікування. Варіанти терапії включають в себе загальне і місцеве лікування гострого захворювання, а також профрілактичні заходи при рецидивному перебігу. Місцеве лікування складається 3 місцевих антисептиків для ерозованих шкірних уражень і антисептичних/ антигістамінних полоскань і місцевих анестезувальних розчинів при ураженні порожнини рота. Призначення 


\section{ОГЛЯДИ ТА ЛЕКЦІї}

місцевих очних лікувальних засобів має здійснюватися у співпраці з окулістом.

Не існує подвійних сліпих або відкритих досліджень загальних методів лікування для гострого епізоду БЕ. Коли пусковий фрактор виявити можливо (наприклад, ВПГ або Mycoplasma pneumoniae), слід почати специфрічне лікування; у разі ВПГ - це супресивна терапія. У більшості випадків БЕ, особливо малої форми, зазвичай буває достатньо симптоматичного лікування, легкі випадки не лікують. Антигістамінні засоби всередину протягом 3-4 днів можуть зменшити печіння і свербіж шкіри [6].

Хворі з множинними мішенеподібними елементами і тяжкою формою БЕ з функціональними порушеннями швидко відповідають на 1-3-тижневий курс преднізолону. Преднізолон (0,5-1,0 мг/кг) продовжують приймати до досягнення контролю (усунення або полегшення симптомів захворювання). Другим варіантом системного лікування глюкокортикоїдами $€$ пульс-терапія метилпреднізолоном у дозі 20 мг/кг/добу впродовж 3-х послідовних днів. Лікування за допомогою преднізолону може успішно обірвати рецидив [14].

Ацикловір при застосовуванні безперервно по 400 мг 2 рази на добу запобігає ГАБЕ у багатьох випадках. Деякі пацієнти використовували цей препарат безперервно впродовж багатьох років без будь-яких явних побічних ефектів.

Хворі з рецидивною БЕ повинні отримувати ацикловір впродовж 6 міс. Валацикловір і фрамцикловір всмоктуються краще, ніж ацикловір, і можуть використовуватися у хворих, які не відповідають на ацикловір. Якщо ці способи лікування безрезультатні, можна спробувати дапсон або антималярійні засоби. Азатіоприн успішно використовували у пацієнтів з тяжким захворюванням, у яких всі інші способи лікування не дали успіху. Відповідь на лікування була дозозалежною (100-150 мг/добу). Після переривання лікування спостерігалися рецидиви.

Герпес-асоційована багатоформна еритема $є$ різновидом інфекційно-алергічної фрорми багатоформної еритеми. ГАБЕ розвивається в терміни до 14 діб після типового рецидиву ПГ, підтвердженого полімеразноланцюговою реакцією. Для ГАБЕ характерні часті рецидиви - 5-12 разів на рік, характеристика висипу відрізняється від такої при токсико-алергічній БЕ. Перед розвитком ГАБЕ спостерігаються зміни клінічного перебігу ПГ: зростає частота рецидивів ПГ - в середньому удвічі, збільшується тривалість рецидивів, вони стають нечутливими до терапії, яка раніше з успіхом застосовувалася, може зростати обсяг ураженої ПГ шкіри. Максимально вираженими для ГАБЕ $є$ такі зміни імунного статусу: зниження вмісту $\lg$ А, підвищення рівня $\operatorname{lgE}$, підвищення спонтанної продукції ІЛ-4 та ІЛ-6 на тлі зниження їх індукованої продукції, зниження числа натуральних кілерів та інтерферону (ІФН- $\alpha$ і ІФН- $\gamma)$, підвищення абсолютної кількості В-лімфоцитів. Метод терапії загострення ГАБЕ залежить від стадії ПГ. При розвитку ГАБЕ в активну (везикульозну) стадію ПГ ефективний прийом синтетичних нуклеозидів. Пацієнтам, організм яких відновив контроль над вірусом ПГ (клінічно у них крустозна стадія ПГ), показане введення дипроспану в поєднанні з пероральним прийомом синтетичних нуклеозидів. При розвитку ознак імпетиго й інтоксикаційного синдрому рекомендований пероральний прийом антибіотиків широкого спектру дії. Надалі для профілактики ГАБЕ ефективне призначення герпетичної полівакцини -2 курси по 5 ін'єкцій в дозі 0,1-0,2-0,3-0,3-0,3 мл з двотижневою перервою між курсами; ревакцинація через 6 міс.; повторення курсу вакцинації на наступний рік для закріплення результату. При неефективності герпетичної полівакцини доцільне використання рекомбінантних препаратів, наприклад віферону. Проорілактика БЕ полягає у лікуванні герпесвірусної інорекції, тривалому прийомі противірусних препаратів. При появі перших елементів захворювання слід негайно починати противірусну терапію, щоб уникнути запуску токсико-алергічного синдрому.

На сьогодні немає чітких рекомендацій щодо терапії таких хворих, зокрема дозування та тривалості противірусної терапії. Тому існує нагальна потреба у розробці клінічних настанов із лікування пацієнтів 3 герпес-асоційованою багатоформною еритемою.

\section{Література}

1. Ванжа А.Ю. Случай идиопатической многоформной экссудативной эритемы при применении препарата Ламизила / А.Ю. Ванжа, О.Н. Леухин // Актуальные вопросы дерматовенерологии. - 2000. - Вып. 3. - С. 21-23.

2. Иванов О.Л. Многоформная экссудативная эритема, клинические, иммунологические и терапевтические особенности / О.Л. Иванов, М.В. Халдина // Лечащий врач. - 2003. - № 9. - С. 4-9.

3. Самгин М.А. Валтрекс в терапии больных многоформной экссудативной эритемой, ассоциированной с Herpes simplex / М.А. Самгин, А.А. Халдин // Росс. журн. кожных и венерических болезней. - 2000. - № 2. - С. 34-36.

4. A study on Epstein-Barr virus in erythema multiforme / [C.L. Chen, K.C. Chow, C.K. Wong et al.] // Arch. Dermatol. Res. 1998. - Vol. 290, N 8. - P. 446-449.

5. Molnar I. Arthritis associated with recurrent erythema multiforme responding to oral acyclovir / I. Molnar, M. Matulis // Clin. Rheumatol. - 2002. - Vol. 21, N 5. - Р. 415-417.

6. Рюмин Д.В. Эритема экссудативная многоформная / Д.В. Рюмин, В.Н. Шеварова // Вестник последипломного медицинского образования. - 2002. - № 3. - С. 16-20.

7. Самгин М.А. Терапевтические возможности валтрекса (валацикловира) при простом герпесе и герпесассоциированной многоформной эритеме (обобщение пятилетнего опыта) / М.А. Самгин, А.А. Халдин, М.В. Халдина // Вестник дерматологии и венерологии. - 2003. - № 4. - С. 52-54. 
8. Weston W.L. Atypical forms of herpes simplex-associated erythema multiforme / W.L. Weston, S.L. Brice // J. Am. Acad. Dermatol. - 1998. - Vol. 39, N 1. - P. 12-46.

9. Самгин М.А. Простой герпес (дерматологические аспекты): рук-во для врачей / М.А. Самгин, А.А. Халдин. - М., 2002. - С. 101103.

10. Cohen D.M. Cinnamon-induced oral erythema multiformelike sensitivity reaction / D.M. Cohen, I. Bhattacharyya // J. Am. Dent. Assoc. - 2000. - Vol. 131, N 7. - P. 929-934.

11. Cohen P.R. Herpes simplex virus-induced recurrent erythema multiforme / P.R. Cohen // J. Gt. Houst. Dent. Soc. - 1995. - Vol. 66, N 9. - P. 17-18.

12. Goldberg L.H. Erythema multiforme due to herpes simplex: treatment with oral acyclovir / L.H. Goldberg, J. Sperber // South. Med. J. - 1986. - Vol. 79, N 6. - P. 757-759.

13. Коновалова М.В. Многоформная экссудативная еритема / М.В. Коновалова, В.Н. Гребенюк // Вестник дерматологии и венерологии. - 1992. - № 3. - С. 20-25.

14. Халдин А.А. Изучение эффрективности различных методов терапии больных рецидивирующим герпесом с использованием индуктора интерферона ридостима и рекомбинантного альфа2-интерферона: автореср. дисс ... канд. мед. наук / А.А. Халдин. - M., 1995. - 19 c.

15. Onishi I. Erythema multiforme after resolution of herpes zoster by acyclovir / I. Onishi, S. Kishimoto // Eur. J. Dermatol. - 2002. Vol. 12, N 4. - P. 370-372.

16. Stanberry L.R. Herpes. Vaccines for HSV / L.R. Stanberry // Dermatol. Clin. - 1998. - Vol. 16, N 4. - P. 811-816.
17. Amichai B. Herpes simplex virus associated erythema multiforme in a prepartum woman without involvement of the newborn / B. Amichai, S. Meltzer // J. Eur. Acad. Dermatol. Venereol. - 2002. - Vol. 16, N 5. - P. 546.

18. Возгомент О.В. Опыт применения гемосорбции в интенсивной терапии синдрома Стивенса-Джонсона у ребенка / О.В. Возгомент, В.Н. Грязнов, С.Л. Медведев // Анестезиология и реаниматология. - 1989. - № 6. - С. 46-47.

19. Huff J.C. Recurrent erythema multiforme / J.C. Huff, W.L. Weston // Medicine (Baltimore). - 1989. - Vol. 68, N 3. - P. 133140.

20. James E. Erythema multiforme: A Practical Approach to Recent Advances / E. James, M.D. Rasmussen // Pediatric Derm. - 2002. Vol. 19. - P. 82.

\section{HERPES-ASSOCIATED ERYTHEMA MULTIFORME EXUDATIVE}

S.O. Halnykina

SUMMARY. The paper highlights aspects of the etiology, pathogenesis, diagnosis, treatment and prevention of herpes-associated erythema banatoformnoyi. The basic aspects of the differential diagnosis between large, small form BE and Stevens-Johnson syndrome.

Key words: erythema multiforme, herpes simplex virus, skin lesions.

Отримано 19.10.2015 р. 